\title{
Rate-Determining Steps of Oxygen Surface Exchange Kinetics on $\mathrm{Sr}_{2} \mathrm{Fe}_{1.5} \mathrm{Mo}_{0.5} \mathrm{O}_{6-\delta}$
}

\author{
Denis A. Osinkin 1,2,*, Anna V. Khodimchuk 1,2, Natalia M. Porotnikova ${ }^{1,2}$, \\ Nina M. Bogdanovich ${ }^{1}$, Andrey V. Fetisov ${ }^{3}$ and Maxim V. Ananyev ${ }^{1,2}$ \\ 1 Institute of High-Temperature Electrochemistry UB RAS, Yekaterinburg 620137, Russia; \\ annlocked@gmail.com (A.V.K.); n.porotnikova@mail.ru (N.M.P.); \\ Bogdanovich@ihte.uran.ru (N.M.B.); m.ananyev@mail.ru (M.V.A.) \\ 2 Graduate School of Economics and Management, Ural Federal University, Yekaterinburg 620002, Russia \\ 3 Institute of Metallurgy UB RAS, Yekaterinburg 620016, Russia; fetisov@mail.ru \\ * Correspondence: OsinkinDA@mail.ru
}

Received: 1 December 2019; Accepted: 30 December 2019; Published: 3 January 2020

check for updates

\begin{abstract}
The oxygen surface kinetics of $\mathrm{Sr}_{2} \mathrm{Fe}_{1.5} \mathrm{Mo}_{0.5} \mathrm{O}_{6-\delta}$ was determined using the ${ }^{16} \mathrm{O}_{2} /{ }^{18} \mathrm{O}_{2}$ isotope exchange method with gas phase analysis at $600-800{ }^{\circ} \mathrm{C}$. The heterogeneous exchange rates $\left(r_{H}\right)$ and the oxygen diffusion coefficients $(D)$ were calculated by processing the concentration dependences of the ${ }^{18} \mathrm{O}$ fraction using Ezin's model. The rates of oxygen dissociative adsorption $\left(r_{\mathrm{a}}\right)$ and incorporation $\left(r_{\mathrm{i}}\right)$ were calculated based on a model using the three exchange type rates. It has been established that the rates $r_{\mathrm{a}}$ and $r_{\mathrm{i}}$ were comparable in this temperature range. Assumptions were made about the effect of the chemical composition of the surface on the rate of oxygen adsorption. It was found that the oxygen exchange coefficient $(k)$ of $\mathrm{Sr}_{2} \mathrm{Fe}_{1.5} \mathrm{Mo}_{0.5} \mathrm{O}_{6-\delta}$ is comparable to that of $\mathrm{La}_{0.6} \mathrm{Sr}_{0.4} \mathrm{MnO}_{3 \pm \delta}$ oxide. High values of the oxygen diffusion coefficient were found for $\mathrm{Sr}_{2} \mathrm{Fe}_{1.5} \mathrm{Mo}_{0.5} \mathrm{O}_{6-\delta}$. The values were comparable to those of the double cobaltite praseodymium-barium and exceed by more than an order those of lanthanum-strontium manganite.
\end{abstract}

Keywords: $\mathrm{Sr}_{2} \mathrm{Fe}_{1.5} \mathrm{Mo}_{0.5} \mathrm{O}_{6-\delta}$; oxygen surface kinetics; heterogeneous exchange rate; oxygen diffusion coefficient; oxygen adsorption; oxygen incorporation; $\mathrm{X}$-ray photoelectron spectroscopy

\section{Introduction}

One of the promising areas of development and creation of electrochemical devices is the search for materials with satisfactory physicochemical and electrochemical characteristics. This includes the search for electrode materials for Solid-oxide fuel cells (SOFC). Oxide materials with the like-perovskite structure have been recommended as cathode materials [1-5]. Recently, $\mathrm{Sr}_{2} \mathrm{Fe}_{1.5} \mathrm{Mo}_{0.5} \mathrm{O}_{6-\delta}$ (SFM) oxide has been suggested as a promising material for electrochemical devices with symmetrical (i.e., with identical) electrodes [6,7] due to the high stability and electrical conductivity of SFM under oxidizing and reducing conditions [8-19]. The rates of hydrogen oxidation and oxygen reduction reactions are also quite high for these electrodes. The polarization resistance can be significantly reduced, by an order of magnitude, by doping crystal lattice, impregnating electrodes, or modifying the microstructure of electrodes [17-26].

A feature of the SFM electrode is a lower electrochemical activity under oxidizing conditions, when compared to a reducing one. Such behavior of the SFM-based electrodes was shown in [14,27]. This is due to the different modes of the electrode reaction and the rate-determining stages in the oxidizing and reducing atmospheres, demonstrated by analyzing the Distribution of relaxation times (DRT) functions of the SFM electrodes [27]. It should be noted that the kinetics of oxygen reduction on the SFM electrode is not well understood. For example, W. Sun et al. [28] demonstrated that the limiting 
stage of the electrode reaction was the ionization of adsorbed oxygen. B. He and Y. Wang $[17,29]$ suggested that oxygen ion transfer processes, in particular surface exchange and oxygen diffusion, were limited to the kinetics of oxygen reduction. In our work [24], we concluded that the low electrochemical activity of SFM in air was associated with a low rate of oxygen exchange on the surface, based on a comparison of the DRT function of the SFM electrode in the air atmosphere before and after the introduction of praseodymium oxide into the SFM electrode.

In the present work, the isotope exchange method with gas phase analysis was used to study the oxygen exchange kinetics of SFM with the gas phase. The advantage of this method is the direct determination of the oxygen exchange and oxygen diffusion coefficients. Several works are known in which the chemical exchange coefficients in various atmospheres were shown [29-31]. However, the rate-determining stages of the oxygen heterogeneous exchange have not been determined. The aim of this research was the detailed study of the oxygen exchange kinetics of SFM with gas phase by the isotopic exchange technique with gas phase analysis, to determine the nature of the rate-determining steps of oxygen heteroexchange.

\section{Materials and Methods}

The SFM powder was obtained by solid state synthesis by mixing $\mathrm{Sr}\left(\mathrm{NO}_{3}\right)_{2}, \mathrm{Fe}_{2} \mathrm{O}_{3}$, and $\mathrm{MoO}_{3}$ (the concentration of the main component was not less than 99.5\%). The synthesis was carried out in two stages at temperatures of $750^{\circ} \mathrm{C}$ for $2 \mathrm{~h}$ and $1100^{\circ} \mathrm{C}$ for $10 \mathrm{~h}$ in air. The $\mathrm{X}$-ray powder diffraction (XRD) pattern of SFM powder was shown in our previous paper [32]. X-ray powder diffraction (XRD) and structural analysis were carried out by using the D/MAX-2200 RIGAKU conventional diffractometer in $\mathrm{CuK} \alpha$-radiation $(\lambda(\mathrm{K} \alpha 1)=1.54 \AA)$ at room temperature in ambient air. The diffraction pattern was collected in the $2 \theta$ range of $10^{\circ}-70^{\circ}$ with steps of $0.02^{\circ}$. The program Fullprof was used for the Rietveld refinement of the crystal structure of the compound. According to the XRD powder analysis pattern, the SFM oxide does not have any impurities. All the diffraction peaks of the SFM could be indexed as a cubic perovskite unit cell (space group Pm $\overline{3} \mathrm{~m}, \mathrm{a}=3.9227(6) \AA$ [33]), which is in agreement with the literature [34]. Dry SFM powder (without a binder) was pressed into tablets and sintered at $1250^{\circ} \mathrm{C}$ for $10 \mathrm{~h}$ in ambient air. After sintering, the tablets were mechanically thinned to $1 \mathrm{~mm}$ and polished on both sides using two types of diamond paste (ASM 7/5 NVM, grit size 5-7 $\mu \mathrm{m}$, and ASM 1/0 NOM, grit size $1 \mu \mathrm{m}$ ). After that, the samples were cleaned in an ultrasonic bath in three stages, sequentially: in distilled water, isopropyl alcohol, and acetone for $20 \mathrm{~min}$ each.

The cross-section of the sample was made for taking micrographs. For this, a dense sample was placed in an epoxy resin under vacuum, kept until it hardened, and polished using a Struers Labopol device. The SEM images and the map of element distribution were obtained using an electron microscope MIRA 3LMU with the X-ray energy-dispersive microanalysis system.

$\mathrm{X}$-ray photoelectron spectra were obtained by the spectrometric complex Multiprob. The radiation of an X-ray source of $\mathrm{MgK}_{\alpha}$ with an energy of $1253.6 \mathrm{eV}$ was used.

The kinetics of oxygen isotope exchange between gas-phase oxygen and SFM oxide was studied in the temperature range $600-800^{\circ} \mathrm{C}$ at an oxygen pressure $P_{\mathrm{O}_{2}}=10^{-2} \mathrm{~atm}$. Enriched ${ }^{18} \mathrm{O}$ oxygen was used as a label, the proportion of which in the mixture was $83.6 \%$. A detailed description of the experimental procedure, the assessment of the accuracy of the determination of the heterogeneous exchange rate $\left(r_{H}\right.$, atom $\left.\mathrm{cm}^{-2} \mathrm{~s}^{-1}\right)$ and the oxygen diffusion coefficient $\left(D, \mathrm{~cm}^{2} \mathrm{~s}^{-1}\right)$, and the calculation of the dissociative adsorption rate $\left(r_{\mathrm{a}}\right.$, atom $\left.\mathrm{cm}^{-2} \mathrm{~s}^{-1}\right)$ and the oxygen incorporation rate $\left(r_{\mathrm{i}}\right.$, atom $\left.\mathrm{cm}^{-2} \mathrm{~s}^{-1}\right)$ are described in [35-37]. During the experiment, periodical changes in the ion current corresponding to the masses 32,34 , and $36\left({ }^{16} \mathrm{O}_{2},{ }^{16} \mathrm{O}^{18} \mathrm{O},{ }^{18} \mathrm{O}_{2}\right)$ were recorded using a quadrupole mass spectrometer Agilent 5973N.

\section{Results and Discussion}

The SEM image processing analysis by the ImageJ program indicated that the porosity of SFM was about $8 \%$. An increase in the sintering time did not lead to a significant change in the porosity. 
An increase in the sintering temperature by $50{ }^{\circ} \mathrm{C}$ led to the melting of the material. The energy dispersive $\mathrm{X}$-ray analysis revealed a homogeneous distribution of $\mathrm{Fe}$, $\mathrm{Sr}$, and Mo cations on the surface layer of SFM (Figure 1).

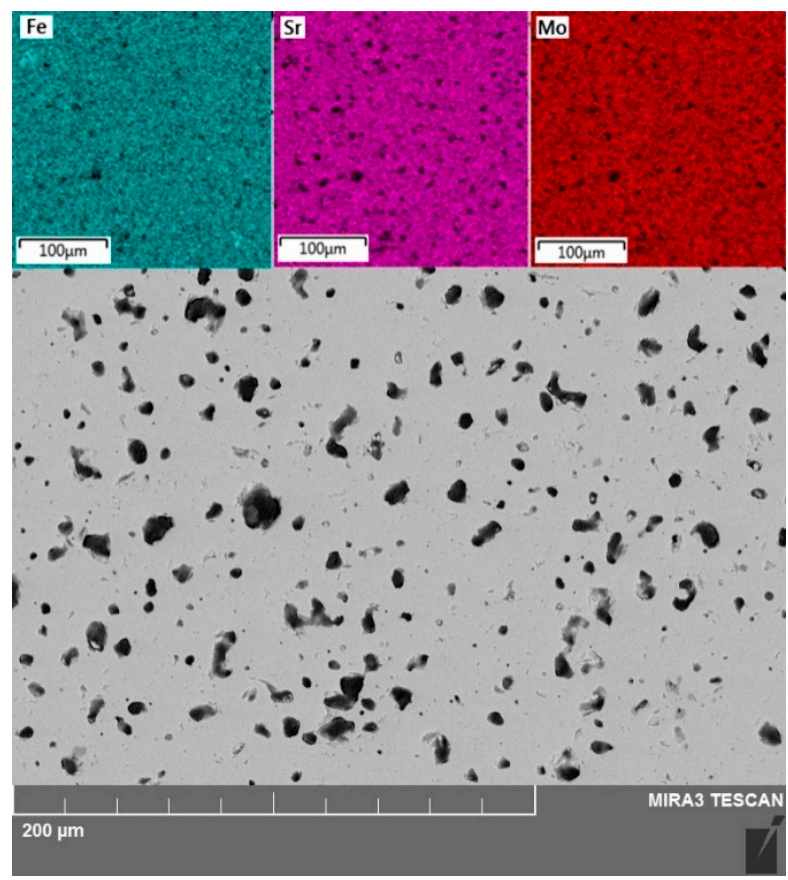

Figure 1. SEM image of $\mathrm{Sr}_{2} \mathrm{Fe}_{1.5} \mathrm{Mo}_{0.5} \mathrm{O}_{6-\delta}$ (SFM) surface and energy dispersive maps for $\mathrm{Fe}, \mathrm{Sr}$, and Mo.

The typical dependences of the fraction of isotope ${ }^{18} \mathrm{O}$ in the gas phase under experimental conditions are shown on Figure 2. The dependence type has an exponential form, i.e., kinetics was complicated by oxygen diffusion. Two kinetic equations related to ${ }^{18} \mathrm{O}$ in the gas phase ( $\alpha$, alpha) and the deviation of the ${ }^{18} \mathrm{O}_{2}$ concentration from the equilibrium $(\dot{Z})$ were used to describe the kinetics of isotopic exchange:

$$
\left\{\begin{array}{l}
\dot{\alpha}=r_{H}\left(\alpha_{S}-\alpha\right) \\
\dot{Z}=C_{36}-C_{36}^{\infty}
\end{array}\right.
$$

where $\dot{\alpha}$-change in the concentration of ${ }^{18} \mathrm{O}$ in the gas phase; $\alpha_{\mathrm{s}}$-the fraction of the oxygen isotope on the surface. These equations and the following are written as dimensionless quantities to simplify perception.
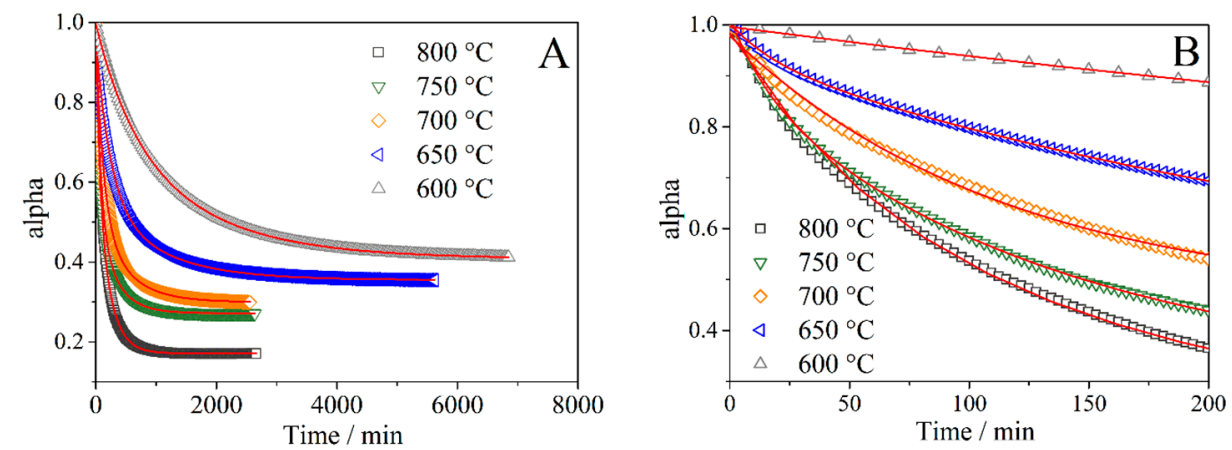

Figure 2. The dependence of the ${ }^{18} \mathrm{O}$ oxygen isotope fraction in the gas phase (alpha) on the time at $P_{\mathrm{O} 2}=10^{-2} \mathrm{~atm}$. (A) and fragment of the dependence of the initial section (B). 
The experimental data are described using the model obtained by A. Ezin et al. [38], based on the decision of K. Klier et al. [39]. The model is the result of solving a system of two equations with boundary and initial conditions:

$$
\left\{\begin{array}{l}
\frac{N}{S} \dot{\alpha}=r_{H}\left(\alpha_{S}-\alpha\right) \\
\frac{N}{S} \dot{y}=-r y+2 r_{2}\left(\alpha_{S}-\alpha\right)^{2} \\
\dot{\alpha}=D \nabla^{2} \alpha \\
r=r_{0}+r_{1}+r_{2}
\end{array}\right.
$$

where $S$ is the surface area of the sample; $N$ is the amount of oxygen in the gas phase; $\alpha$ is the ${ }^{18} \mathrm{O}$ fraction; $y$ is the value equal to the difference between the concentration of ${ }^{18} \mathrm{O}^{16} \mathrm{O}$ molecules at time $t$ from the equilibrium value; $r$ is the sum of the rates of the three types of exchange. The first type of exchange $r_{0}$ occurs without the participation of oxygen oxide; one and two oxygen atoms from the oxide surface participate in the exchange of the second $r_{1}$ and third $r_{2}$ types, respectively.

Figure 3 shows the temperature dependence of the oxygen exchange and diffusion coefficients for SFM oxide at an oxygen pressure of $P_{\mathrm{O}_{2}}=10^{-2} \mathrm{~atm}$. The results are given in comparison with the data from [30] for SFM.

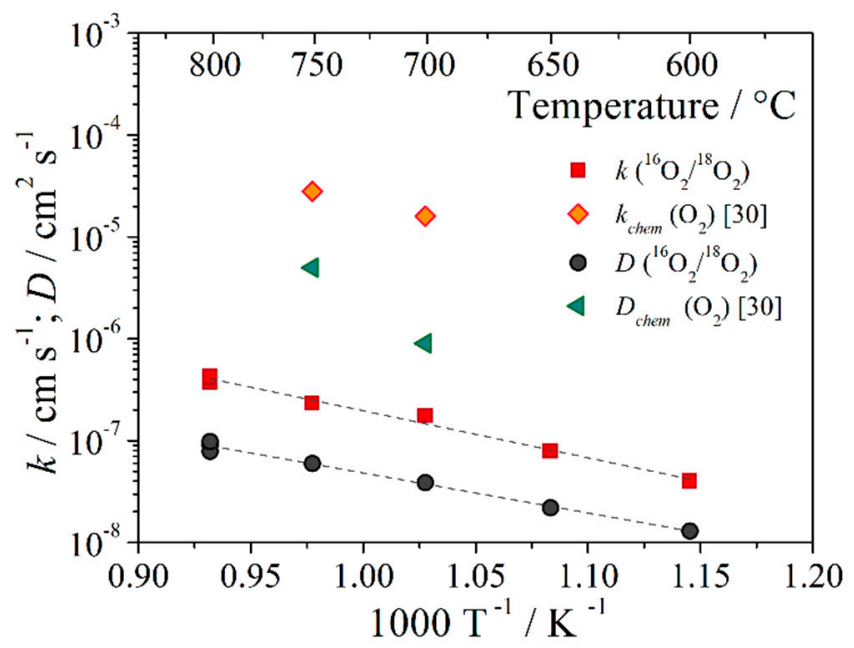

Figure 3. Temperature dependence of oxygen surface exchange and diffusion coefficients for oxide $\mathrm{Sr}_{2} \mathrm{Fe}_{1.5} \mathrm{Mo}_{0.5} \mathrm{O}_{6-\delta}$.

The ratio for recalculation was used to compare the values of the oxygen heterogeneous rate $\left(r_{H}\right)$ with the published data of the oxygen surface exchange coefficient $(k)$ :

$$
k=r_{H} \frac{M_{r}}{(6-\delta) N_{A} \rho}
$$

where $r_{H}$ is the oxygen heterogeneous rate $\left(\right.$ atom $\left.\mathrm{cm}^{-2} \mathrm{~s}^{-1}\right) ; k$ is the oxygen surface exchange coefficient $\left(\mathrm{cm} \mathrm{s}^{-1}\right) ; M_{r}$ is the molecular mass; $N_{A}$ is the Avogadro constant; and $\rho$ is the crystallographic density.

An earlier work led by H.J.M. Bouwmeester studies the surface oxygen exchange coefficients of $\mathrm{Sr}_{2} \mathrm{Fe}_{1.5} \mathrm{Mo}_{0.5} \mathrm{O}_{6-\delta}$ oxide in atmospheres $\mathrm{CO}+\mathrm{CO}_{2}$ and $\mathrm{H}_{2}+\mathrm{H}_{2} \mathrm{O}$, obtained by the method of relaxation of electrical conductivity $[29,31]$. It can be noted that in the reducing atmosphere $\left(\mathrm{P}_{\mathrm{O}_{2}}\right.$ change from 0.1 to $1 \mathrm{~atm}$.) the chemical oxygen exchange coefficient was an order of magnitude higher than the values in the oxidizing atmosphere $\left(\mathrm{PO}_{2}\right.$ change from $2.6 \times 10^{-23}$ to $9.4 \times 10^{-24} \mathrm{~atm}$.) at $750{ }^{\circ} \mathrm{C}: 2.3 \times 10^{-6}$ and $3.7 \times 10^{-7} \mathrm{~m} \mathrm{~s}^{-1}$, respectively [31]. We also obtained a tendency to increase the coefficient of oxygen exchange from temperature by the method of oxygen isotope exchange; the activation energy was $0.91 \pm 0.03 \mathrm{eV}$ (Figure 3). The oxygen heterogeneous coefficient $\left(r_{H}\right)$ was recalculated into the oxygen exchange coefficient according to Equation (3); a value equal to $3.7 \times 10^{-9} \mathrm{~m} \mathrm{~s}^{-1}$ at $750{ }^{\circ} \mathrm{C}$ was obtained, 
which is two orders of magnitude lower than the chemical coefficient. There were also differences in the values of the oxygen diffusion coefficient and the chemical diffusion coefficient. It is likely that charge transfer, oxygen vacancies, and exchangeable oxygen can significantly affect the differences in values. In confirmation, SFM compounds have a mixed ionic and electronic conductivity. However, the electronic conductivity is much higher than the ionic one [28]. The activation energy of the oxygen diffusion coefficient was $0.78 \pm 0.03 \mathrm{eV}$ in the temperature range $600-800^{\circ} \mathrm{C}$. This value is comparable to the activation energy of oxygen flows through $\mathrm{Sr}_{2} \mathrm{Fe}_{1.5} \mathrm{Mo}_{0.5} \mathrm{O}_{6-\delta}$, equal to $E_{a}=0.798 \mathrm{eV}$ [17]. This indirectly suggests that the obtained value of $D$ corresponds only to the ionic diffusion coefficient.

The values of the individual stages of oxygen adsorption $\left(r_{a}\right.$, atom $\left.\mathrm{cm}^{-2} \mathrm{~s}^{-1}\right)$ and incorporation $\left(r_{i}\right.$, atom $\left.\mathrm{cm}^{-2} \mathrm{~s}^{-1}\right)$ were calculated to determine the rate-determining process of the interaction of oxygen in the gas phase and the oxide oxygen by the model based on the use of the values of three types of exchange: $r_{0}, r_{1}$, and $r_{2}$ [37], where $\mathrm{O}_{a}$ corresponds to the adsorption site and $\mathrm{O}_{s}$ is the incorporated oxygen:

$$
\begin{gathered}
\mathrm{O}^{18} \mathrm{O}+{ }^{16} \mathrm{O}_{a} \stackrel{r_{a}}{=} \mathrm{O}^{16} \mathrm{O}+{ }^{18} \mathrm{O}_{a} \\
{ }^{18} \mathrm{O}_{a}+{ }^{16} \mathrm{O}_{s} \stackrel{r_{i}}{=}{ }^{16} \mathrm{O}_{a}+{ }^{18} \mathrm{O}_{s} \\
r_{0}=r_{a}\left(1-\frac{r_{i}}{r_{a}+r_{i}}\right)^{2} \\
r_{1}=2 \frac{r_{a} r_{i}}{r_{a}+r_{i}}\left(1-\frac{r_{i}}{r_{a}+r_{i}}\right) \\
r_{2}=r_{a}\left(\frac{r_{i}}{r_{a}+r_{i}}\right)^{2} \\
r=r_{a}=r_{0}+r_{1}+r_{2} \\
r_{i}=\frac{r_{a} r_{H}}{r_{a}-r_{H}} .
\end{gathered}
$$

Figure 4 shows the temperature dependences of the rates of oxygen heterogeneous exchange, adsorption, and incorporation at an oxygen pressure $\mathrm{P}_{2}=10^{-2} \mathrm{~atm}$. The oxygen incorporation and adsorption rates were comparable in the $600-800^{\circ} \mathrm{C}$ temperature range. The activation energy of oxygen incorporation $(0.87 \pm 0.07 \mathrm{eV})$ was close to the activation energy of oxygen diffusion $(0.78 \pm 0.03 \mathrm{eV})$; we can conclude that the stage of oxygen incorporation step for $\mathrm{Sr}_{2} \mathrm{Fe}_{1.5} \mathrm{Mo}_{0.5} \mathrm{O}_{6-\delta}$ was limited by oxygen diffusion from the bulk to the surface. In this case, it is not clear why the incorporation rate was comparable to the adsorption rate, since the diffusion coefficient was quite high. The oxygen adsorption rate can be significantly affected by the state of the sample surface. Therefore, studies have been conducted on the elemental composition of surfaces by the XPS method (Figure 5). The presence of all elements on the surface was determined from the results for a dense sample after isotopic measurements; their ratio was defined as $\mathrm{A}_{2} \mathrm{~B}_{2} \mathrm{O}_{6-\delta}-13.5: 14.1: 72.4 \mathrm{~mol} \%$, which is close to the formula unit. However, for iron and molybdenum the ratio was not retained and was equal to $8.2: 5.9 \mathrm{~mol} \%$. All values are indicated as a percentage of the stoichiometric total number of elements. It can be assumed that surface degradation occurred due to the displacement of heavier ions from the volume to its surface. To understand the processes of oxygen exchange on the surface, we considered the bond strength of $\mathrm{Fe}-\mathrm{O}$ and Mo-O. According to Shannon [40], the effective ionic radii for ${ }^{\mathrm{VI}} \mathrm{Mo}^{+6}$ is $0.59 \AA$ and for ${ }^{\mathrm{VI}} \mathrm{Fe}^{+3} 0.65 \AA$. From this, it follows that the Mo-O bond is shorter than the $\mathrm{Fe}-\mathrm{O}$ bond; therefore, the binding energy for Mo-O is higher, which indicates a stronger bond. These results show a good agreement with the crystallographic structure obtained by the structural refinement results for $\mathrm{Sr}_{2} \mathrm{Fe}_{1.5} \mathrm{Mo}_{0.5} \mathrm{O}_{6-\delta}$ from powder neutron diffraction. In particular, the $\mathrm{Fe}-\mathrm{O}$ and $\mathrm{Mo}-\mathrm{O}$ distances were close to the average values $(\mathrm{rFeO}=1.945(6) \AA, \mathrm{rMoO}=1.928(9) \AA)$ reported in [41], confirming that the Mo-O distance is slightly shorter $(\sim 0.02 \AA)$ than the $\mathrm{Fe}-\mathrm{O}$ one. Thus, it turns out that the Mo-O bond is more difficult to break, which is directly related to oxygen adsorption on the surface. Thus, 
an increase in the concentration of molybdenum on the surface apparently leads to a decrease in the rate of oxygen adsorption.

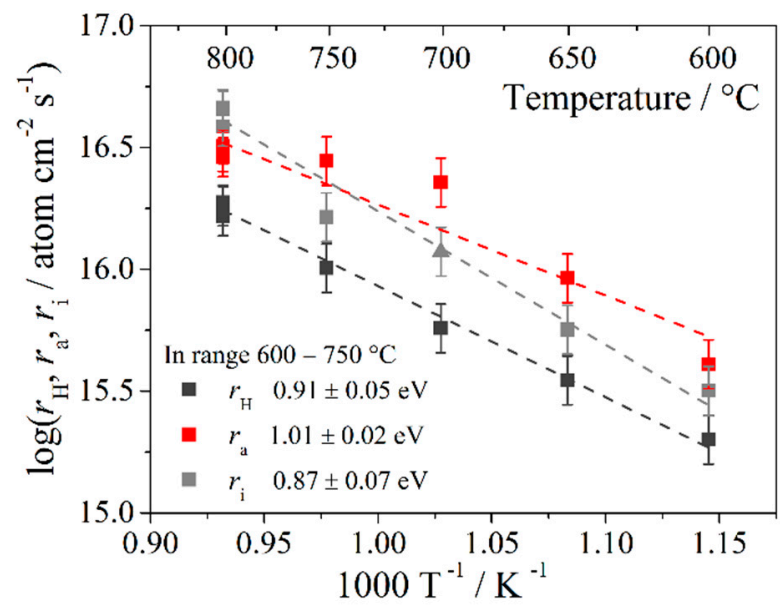

Figure 4. Temperature dependence of the oxygen heterogeneous exchange rate $\left(r_{H}\right)$, oxygen adsorption rate $\left(r_{a}\right)$, and oxygen incorporation rate $\left(r_{i}\right)$ of $\mathrm{Sr}_{2} \mathrm{Fe}_{1.5} \mathrm{Mo}_{0.5} \mathrm{O}_{6-\delta}$ oxide at $P_{\mathrm{O}_{2}}=10^{-2} \mathrm{~atm}$.
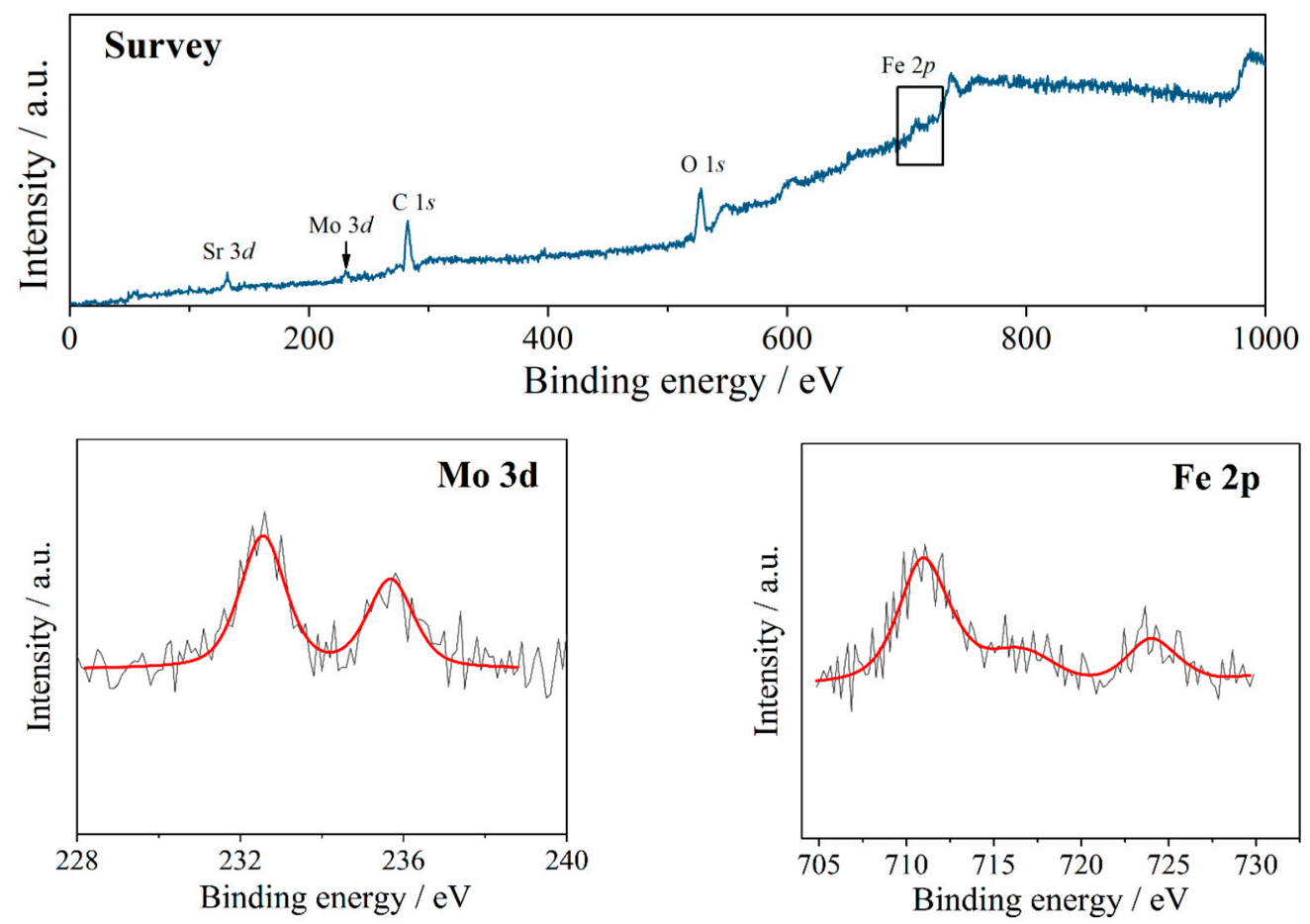

Figure 5. X-ray photoelectron spectra for $\mathrm{Sr}_{2} \mathrm{Fe}_{1.5} \mathrm{Mo}_{0.5} \mathrm{O}_{6-\delta}$.

The temperature dependences of the oxygen surface exchange and diffusion coefficients for different oxides are shown in Figure 6. In these graphs, the oxide materials with perovskite and Ruddlesden-Popper structures were selected as analogues for SFM that could be used as cathode materials in electrochemical devices. The values of the oxygen surface exchange coefficients of strontium ferrite-molybdate were commensurate with $\mathrm{La}_{0.6} \mathrm{Sr}_{0.4} \mathrm{MnO}_{3+\delta}$ oxide. High values of the oxygen diffusion coefficients for $\mathrm{Sr}_{2} \mathrm{Fe}_{1.5} \mathrm{Mo}_{0.5} \mathrm{O}_{6-\delta}$ oxide were obtained; these values were comparable to the values for praseodymium-barium double cobaltite and exceeded the lanthanum-strontium manganite by more than an order of magnitude. 

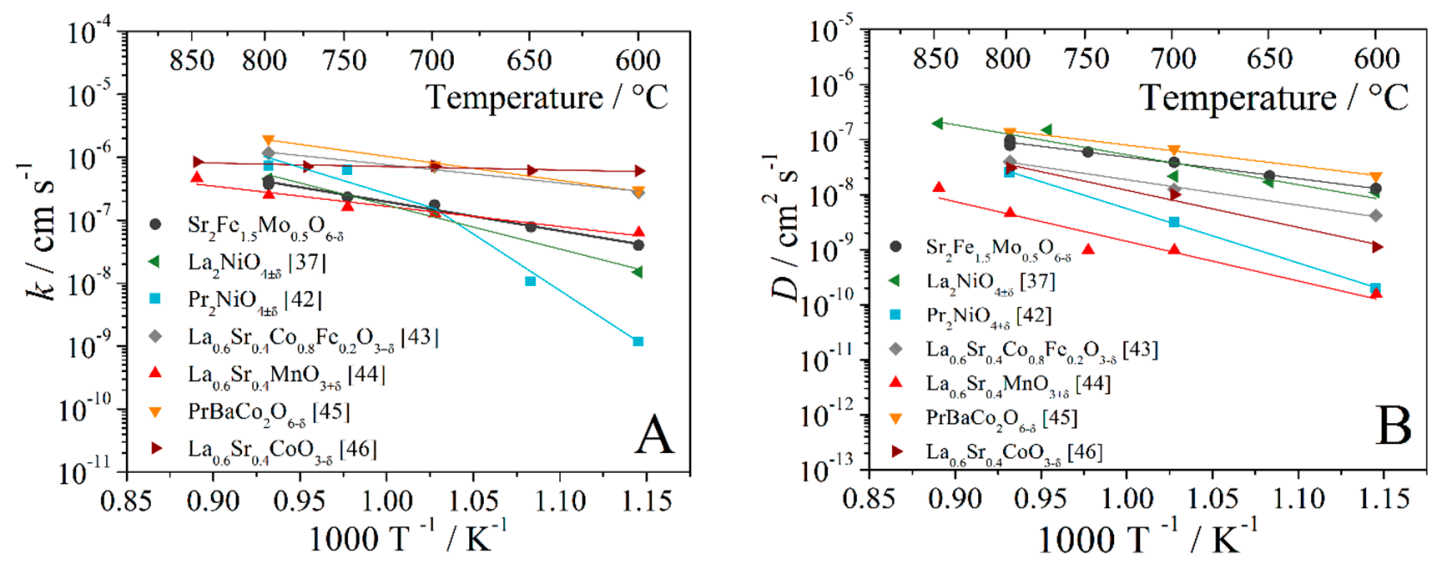

Figure 6. Temperature dependences of the oxygen surface exchange coefficient (A) and the oxygen diffusion coefficient (B) for oxides [37,42-46].

The dependences of the dissociative adsorption and oxygen incorporation rates of some oxides are shown in Figure 7. The values are quite low compared to the rates of identical materials, but overall they are at a good level. The rates of strontium ferrite-molybdate are similar in magnitude to those of cobaltite-ferrite, which is two orders of magnitude higher than the values for lanthanum-strontium manganite.
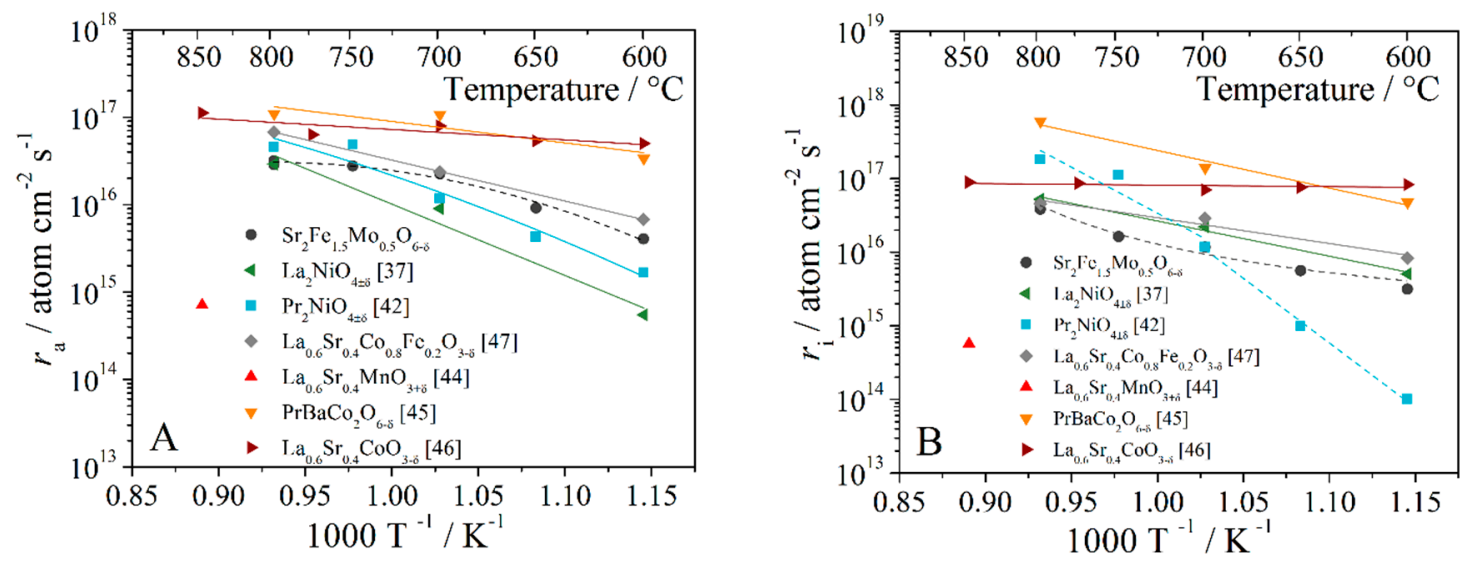

Figure 7. Temperature dependences of the rate of oxygen adsorption (A) and oxygen incorporation (B) for some oxides $[37,42,44-47]$.

The results of this work fully confirmed our hypothesis about the slow oxygen heterogeneous exchange by $\mathrm{Sr}_{2} \mathrm{Fe}_{1.5} \mathrm{Mo}_{0.5} \mathrm{O}_{6-\delta}$ with the gas phase, which we suggested in $[19,22]$, based on the analysis of the impedance spectra of the $\mathrm{Sr}_{2} \mathrm{Fe}_{1.5} \mathrm{Mo}_{0.5} \mathrm{O}_{6-\delta}$ electrode in an oxidizing atmosphere. Although $\mathrm{Sr}_{2} \mathrm{Fe}_{1.5} \mathrm{Mo}_{0.5} \mathrm{O}_{6-\delta}$ oxygen electrodes have high oxygen conductivity and oxygen diffusion coefficients, the rate of electrode reaction to the $\mathrm{Sr}_{2} \mathrm{Fe}_{1.5} \mathrm{Mo}_{0.5} \mathrm{O}_{6-\delta}$ electrode will be limited by the oxygen incorporation rate. To reduce the contribution of this process to the polarization resistance of the oxygen electrode, it is necessary to impregnate the $\mathrm{Sr}_{2} \mathrm{Fe}_{1.5} \mathrm{Mo}_{0.5} \mathrm{O}_{6-\delta}$ electrode with active oxides, for example, praseodymium oxide [19], or add mixed conductors to SFM, for example, based on cerium oxide $[9,20]$, or increase the concentration of electronic charge carriers in $\mathrm{Sr}_{2} \mathrm{Fe}_{1.5} \mathrm{Mo}_{0.5} \mathrm{O}_{6-\delta}$, for example, doping with heterovalent cations.

\section{Conclusions}

The heterogeneous exchange rate, the oxygen diffusion coefficient, and the rates of oxygen dissociative adsorption and incorporation for $\mathrm{Sr}_{2} \mathrm{Fe}_{1.5} \mathrm{Mo}_{0.5} \mathrm{O}_{6-\delta}$ were determined at the temperature range $600-800^{\circ} \mathrm{C}$ and the oxygen pressure $10^{-2} \mathrm{~atm}$. It was shown that the oxygen exchange coefficient 
is $4 \times 10^{-8}-4 \times 10^{-7} \mathrm{~cm} \mathrm{~s}^{-1}$ at the temperature range $600-800{ }^{\circ} \mathrm{C}$ and is comparable in value to the exchange rate of lanthanum-strontium manganite. The oxygen diffusion coefficient has high values equivalent to those of praseodymium-barium double cobaltite. The results fully confirmed our assumption expressed in earlier works on the slow oxygen heterogeneous exchange rate of $\mathrm{Sr}_{2} \mathrm{Fe}_{1.5} \mathrm{Mo}_{0.5} \mathrm{O}_{6-\delta}$ with a gas phase. Surface modification probably made a significant contribution to the oxygen adsorption rate. It was shown that in the temperature range $600-800{ }^{\circ} \mathrm{C}$ it is not possible to distinguish the rate-determining stage. We can conclude that this composition is promising as a basis for cathode materials of SOFC, due to its good performance in the reaction of oxygen exchange and stability in the oxidizing atmospheres.

Author Contributions: Conceptualization, D.A.O. and N.M.P.; methodology, N.M.P.; validation, M.V.A. and D.A.O.; formal analysis, D.A.O. and N.M.P.; investigation, A.V.K., N.M.B., and A.V.F.; writing and original draft preparation, D.A.O. and N.M.P.; writing, review, and editing, M.V.A.; visualization, D.A.O. and N.M.P.; supervision, M.V.A.; project administrator, D.A.O.; funding acquisition, D.A.O. All authors have read and agreed to the published version of the manuscript.

Funding: The study was partly financially supported by the Russian Foundation for Basic Research (17-08-00161) and the Russian Federation Government, agreement 02.A03.21.0006 (no. 211).

Acknowledgments: This work was partly carried out using facilities of the shared access center "Composition of Compounds", IHTE, UB RAS. The authors are grateful to V.A. Eremin and A.S. Farlenkov for assisting in the study.

Conflicts of Interest: The authors declare no conflict of interest.

\section{References}

1. Fergus, J.W.; Hui, R.; Li, X.; Wilkinson, D.P.; Zhang, J. Solid Oxide Fuel Cells: Materials Properties and Performance; CRC Press Taylor \& Francis Group: Boca Raton, FL, USA, 2009; p. 295.

2. Kubicek, M.; Cai, Z.; Ma, W.; Yildiz, B.; Hutter, H.; Fleig, J. Tensile Lattice Strain Accelerates Oxygen Surface Exchange and Diffusion in $\mathrm{La}_{1-x} \mathrm{Sr}_{\mathrm{x}} \mathrm{CoO}_{3-\delta}$ Thin Films. ACS Nano 2013, 7, 3276-3286. [CrossRef] [PubMed]

3. Singhal, S.C.; Kendall, K. High Temperature Solid Oxide Fuel Cells: Fundamentals, Design and Applications; Elsevier Advanced Technology: Oxford, UK, 2003; p. 405.

4. Parfitt, D.; Chroneos, A.; Tarancón, A.; Kilner, J.A. Oxygen ion diffusion in cation ordered/disordered $\mathrm{GdBaCo}_{2} \mathrm{O}_{5+\delta}$. J. Mater. Chem. 2011, 21, 2183-2186. [CrossRef]

5. Chroneos, A.; Yildiz, B.; Tarancón, A.; Parfitt, D.; Kilner, J.A. Oxygen diffusion in solid oxidefuel cell cathode and electrolyte materials: Mechanistic insights from atomistic simulations. Energy Environ. Sci. 2011, 4, 2774-2789. [CrossRef]

6. Ruiz-Morales, J.C.; Marrero-Lopez, D.; Canales-Vazquez, J.; Irvine, J.T.S. Symmetric and reversible solid oxidefuel cells. RSC Adv. 2011, 1, 1403-1414. [CrossRef]

7. Liu, Q.; Dong, X.; Xiao, G.; Zhao, F.; Chen, F. A novel electrode material for symmetrical SOFCs. Adv. Mater. 2010, 22, 5478-5482. [CrossRef] [PubMed]

8. Feng, J.; Yang, G.; Dai, N.; Wang, Z.; Sun, W.; Rooney, D.; Qiao, J.; Sun, K. Investigation into the effect of Fe-site substitution on the performance of $\mathrm{Sr}_{2} \mathrm{Fe}_{1.5} \mathrm{Mo}_{0.5} \mathrm{O}_{6-\delta}$ anodes for SOFCs. J. Mater. Chem. 2014, 2 , 17628-17634. [CrossRef]

9. Dai, N.; Wang, Z.; Jiang, T.; Feng, J.; Sun, W.; Qiao, J.; Rooney, D.; Sun, K. A new family of barium-doped $\mathrm{Sr}_{2} \mathrm{Fe}_{1.5} \mathrm{Mo}_{0.5} \mathrm{O}_{6-\delta}$ perovskites for application in intermediate temperature solid oxide fuel cells. J. Power Sources 2014, 268, 176-182. [CrossRef]

10. Hou, M.; Sun, W.; Li, P.; Feng, J.; Yang, G.; Qiao, J.; Wang, Z.; Rooney, D.; Feng, J.; Sun, K. Investigation into the effect of molybdenum-site substitution on the performance of $\mathrm{Sr}_{2} \mathrm{Fe}_{1.5} \mathrm{Mo}_{0.5} \mathrm{O}_{6-\delta}$ for intermediate temperature solid oxide fuel cells. J. Power Sources 2014, 272, 759-765. [CrossRef]

11. Li, Y.; Zou, S.; Xia, C. Characteristics of nano-structured SFM infiltrated onto YSZ backbone for symmetrical and reversible solid oxide cells. Solid State Ion. 2018, 319, 98-104. [CrossRef]

12. Qiao, J.; Chen, W.; Wang, W.; Wang, Z.; Sun, W.; Zhang, J.; Sun, K. The Ca element effect on the enhancement performance of $\mathrm{Sr}_{2} \mathrm{Fe}_{1.5} \mathrm{Mo}_{0.5} \mathrm{O}_{6-\delta}$ perovskite as cathode for intermediate-temperature solid oxide fuel cells. J. Power Sources 2016, 331, 400-407. [CrossRef] 
13. Miao, G.; Yuan, C.; Chen, T.; Zhou, Y.; Zhan, W.; Wang, S. $\mathrm{Sr}_{2} \mathrm{Fe}_{1+\mathrm{x}} \mathrm{Mo}_{1-\mathrm{x}} \mathrm{O}_{6-\delta}$ as anode material of cathode-supported solid oxide fuel cells. Int. J. Hydrog. Energy 2016, 41, 1104-1111. [CrossRef]

14. Osinkin, D.A.; Beresnev, S.M.; Lobachevskaya, N.I. Symmetrical solid oxide fuel cell with strontium ferrite-molybdenum electrodes. Russ. J. Electrochem. 2017, 53, 665-669. [CrossRef]

15. Yang, Z.; Yang, Y.; Chen, Y.; Liu, Y.; Zhu, T.; Han, M.; Chen, F. Low temperature co-sintering of $\mathrm{Sr}_{2} \mathrm{Fe}_{1.5} \mathrm{Mo}_{0.5} \mathrm{O}_{6-\delta}-\mathrm{Gd}_{0.1} \mathrm{Ce}_{0.9} \mathrm{O}_{2-\delta}$ anode-supported solid oxide fuel cells with $\mathrm{Li}_{2} \mathrm{O}-\mathrm{Gd}_{0.1} \mathrm{Ce}_{0.9} \mathrm{O}_{2-\delta}$ electrolyte. J. Power Sources 2015, 297, 271-275. [CrossRef]

16. Zheng, K.; Swierczek, K.; Polfus, J.M.; Sunding, M.F.; Pishahang, M.; Norby, T. Carbon Deposition and Sulfur Poisoning in $\mathrm{SrFe}_{0.75} \mathrm{Mo}_{0.25} \mathrm{O}_{3-\delta}$ and $\mathrm{SrFe}_{0.5} \mathrm{Mn}_{0.25} \mathrm{Mo}_{0.25} \mathrm{O}_{3-\delta}$ Electrode Materials for Symmetrical SOFCs. J. Electrochem. Soc. 2015, 162, F1078-F1087. [CrossRef]

17. He, B.; Zhao, L.; Song, S.; Liu, T.; Chen, F.; Xia, C. $\mathrm{Sr}_{2} \mathrm{Fe}_{1.5} \mathrm{Mo}_{0.5} \mathrm{O}_{6-\delta}-\mathrm{Sm}_{0.2} \mathrm{Ce}_{0.8} \mathrm{O}_{1.9}$ Composite Anodes for Intermediate-Temperature Solid Oxide Fuel Cells. J. Electrochem. Soc. 2012, 159, B619-B626. [CrossRef]

18. Wang, S.; Hsu, Y.; Huang, M.; Chang, C.; Cheng, S. Characteristics of copper-doped $\operatorname{SrFe}_{0.75} \mathrm{Mo}_{0.25} \mathrm{O}_{3-\delta}$ ceramic as a cathode material for solid oxide fuel cells. Solid State Ion. 2016, 296, 120-126. [CrossRef]

19. Xiao, G.; Wang, S.; Lin, Y.; Han, M.; Chen, F. Ni-doped $\mathrm{Sr}_{2} \mathrm{Fe}_{1.5} \mathrm{Mo}_{0.5} \mathrm{O}_{6-\delta}$ as Anode Materials for Solid Oxide Fuel Cells. J. Electrochem. Soc. 2014, 161, F305-F310. [CrossRef]

20. Osinkin, D.A.; Lobachevskaya, N.I.; Bogdanovich, N.M. Effect of the Copper Oxide Sintering Additive on the Electrical and Electrochemical Properties of Anode Materials Based on $\mathrm{Sr}_{2} \mathrm{Fe}_{1.5} \mathrm{Mo}_{0.5} \mathrm{O}_{6-\delta}$. Russ. J. Appl. Chem. 2017, 90, 1686-1692. [CrossRef]

21. Xiao, G.; Jin, C.; Liu, Q.; Heyden, A.; Chen, F. Ni modified ceramic anodes for solid oxide fuel cells. J. Power Sources 2012, 201, 43-48. [CrossRef]

22. Zhou, Y.; Meng, X.; Ye, X.; Li, J.; Wang, S.; Zhan, Z. Metal-supported solid oxide fuel cells with impregnated $\mathrm{SrFe}_{0.75} \mathrm{Mo}_{0.25} \mathrm{O}_{3}$ cathodes. J. Power Sources 2014, 247, 556-561. [CrossRef]

23. Liu, Q.; Yang, C.; Dong, X.; Chen, F. Perovskite $\mathrm{Sr}_{2} \mathrm{Fe}_{1.5} \mathrm{Mo}_{0.5} \mathrm{O}_{6-\delta}$ as electrode materials for symmetrical solid oxide electrolysis cells. Int. J. Hydrog. Energy 2010, 35, 10039-10044. [CrossRef]

24. Osinkin, D.A.; Beresnev, S.M.; Bogdanovich, N.M. Influence of $\operatorname{Pr}_{6} \mathrm{O}_{11}$ on oxygen electroreduction kinetics and electrochemical performance of $\mathrm{Sr}_{2} \mathrm{Fe}_{1.5} \mathrm{Mo}_{0.5} \mathrm{O}_{6-\delta}$ based cathode. J. Power Sources 2018, 392, 41-47. [CrossRef]

25. Osinkin, D.A.; Lobachevskaya, N.I.; Suntsov, A.Y. The electrochemical behavior of the promising $\mathrm{Sr}_{2} \mathrm{Fe}_{1.5} \mathrm{Mo}_{0.5} \mathrm{O}_{6-\delta}+\mathrm{Ce}_{0.8} \mathrm{Sm}_{0.2} \mathrm{O}_{1.9-\delta}$ anode for the intermediate temperature solid oxide fuel cells. J. Alloy. Comp. 2017, 708, 451-455. [CrossRef]

26. Gao, J.; Meng, X.; Luo, T.; Zhan, Z. Symmetrical solid oxide fuel cells fabricated by phase inversion tape casting with impregnated $\mathrm{SrFe}_{0.75} \mathrm{Mo}_{0.25} \mathrm{O}_{3-\delta}$ (SFMO) electrodes. Int. J. Hydrog. Energy 2017, 42, 18499-18503. [CrossRef]

27. Osinkin, D.A. Kinetics of $\mathrm{CO}$ oxidation and redox cycling of $\mathrm{Sr}_{2} \mathrm{Fe}_{1.5} \mathrm{Mo}_{0.5} \mathrm{O}_{6-\delta}$ electrode for symmetrical solid state electrochemical devices. J. Power Sources 2019, 418, 17-23. [CrossRef]

28. Sun, W.; Li, P.; Xu, C.; Qiao, J.; Wang, Z.; Rooney, D.; Sun, K. Investigation of Sc doped $\mathrm{Sr}_{2} \mathrm{Fe}_{1.5} \mathrm{Mo}_{0.5} \mathrm{O}_{6}$ as a cathode material for intermediate temperature solid oxide fuel cells. J. Power. Sources 2017, 343, 237-245. [CrossRef]

29. Wang, Y.; Hu, B.; Zhu, Z.; Bouwmeester, H.J.M.; Xia, C. Electrical conductivity relaxation of $\mathrm{Sr}_{2} \mathrm{Fe}_{1.5} \mathrm{Mo}_{0.5} \mathrm{O}_{6-\delta}-\mathrm{Sm}_{0.2} \mathrm{Ce}_{0.8} \mathrm{O}_{1.9}$ dual-phase composites. J. Mater. Chem. A 2014, 2, 136-143. [CrossRef]

30. Xiao, G.; Liu, Q.; Zhao, F.; Zhang, L.; Xia, C.; Chen, F. $\mathrm{Sr}_{2} \mathrm{Fe}_{1.5} \mathrm{Mo}_{0.5} \mathrm{O}_{6}$ as Cathodes for Intermediate-Temperature Solid Oxide Fuel Cells with $\mathrm{La}_{0.8} \mathrm{Sr}_{0.2} \mathrm{Ga}_{0.87} \mathrm{Mg}_{0.13} \mathrm{O}_{3}$ Electrolyte. J. Electrochem. Soc. 2011, 158, B455-B460. [CrossRef]

31. Hu, B.; Wang, Y.; Zhu, Z.; Xia, C.; Bouwmeester, H.J.M. Measuring oxygen surface exchange kinetics on mixed-conducting composites by electrical conductivity relaxation. J. Mater. Chem. A 2015, 3, 10296-10302. [CrossRef]

32. Antonova, E.P.; Osinkin, D.A.; Bogdanovich, N.M.; Gorshkov, M.Y.; Bronin, D.I. Electrochemical performance of $\mathrm{Ln}_{2} \mathrm{NiO}_{4+\delta}(\mathrm{Ln}-\mathrm{La}, \mathrm{Nd}, \mathrm{Pr})$ and $\mathrm{Sr}_{2} \mathrm{Fe}_{1.5} \mathrm{Mo}_{0.5} \mathrm{O}_{6-\delta}$ oxide electrodes in contact with apatite-type $\mathrm{La}_{10}\left(\mathrm{SiO}_{6}\right)_{4} \mathrm{O}_{3}$ electrolyte. Solid State Ion. 2019, 329, 82-89. [CrossRef]

33. Osinkin, D.A.; Beresnev, S.M.; Khodimchuk, A.V.; Korzun, I.V.; Lobachevskaya, N.I.; Suntsov, A.Y. Functional properties and electrochemical performance of Ca-doped $\mathrm{Sr}_{2-\mathrm{x}} \mathrm{Ca}_{x} \mathrm{Fe}_{1.5} \mathrm{Mo}_{0.5} \mathrm{O}_{6-\delta}$ as anode for solid oxide fuel cells. J. Solid State Electrochem. 2019, 23, 627-634. [CrossRef] 
34. Garcıa-Landa, B.; Ritter, C.; Ibarra, M.R.; Blasco, J.; Algarabel, P.A.; Mahendiran, R.; Garcıa, J. Magnetic and magnetotransport properties of the ordered perovskite Sr2FeMoO6. Solid State Commun. 1999, 110, 435-438. [CrossRef]

35. Kurumchin, E.K.; Ananjev, M.V.; Vdovin, G.K.; Surkova, M.G. Exchange kinetics and diffusion of oxygen in systems based on lanthanum gallate. Russ. J. Electrochem. 2010, 46, 205-211. [CrossRef]

36. Ananyev, M.V.; Kurumchin, E.K.; Porotnikova, N.M. Effect of oxygen nonstoichiometry on kinetics of oxygen exchange and diffusion in lanthanum-strontium cobaltites. Russ. J. Electrochem. 2010, 46, 789-797. [CrossRef]

37. Ananyev, M.V.; Tropin, E.S.; Eremin, V.A.; Farlenkov, A.S.; Smirnov, A.S.; Kolchugin, A.A.; Porotnikova, N.M.; Khodimchuk, A.V.; Berenov, A.V.; Kurumchin, E.K. Oxygen isotope exchange in $\mathrm{La}_{2} \mathrm{NiO}_{4 \pm \delta}$. Phys. Chem. Chem. Phys. 2016, 18, 9102-9111. [CrossRef] [PubMed]

38. Ezin, A.N.; Tsidilkovski, V.I.; Kurumchin, E.K. Isotopic exchange and diffusion of oxygen in oxides with different bulk and subsurface diffusivities. Solid State Ion. 1996, 84, 105-112. [CrossRef]

39. Klier, K.; Kucera, E. Theory of exchange reactions between fluids and solids with tracer diffusion in the solid. J. Phys. Chem. Solids 1966, 27, 1087-1095. [CrossRef]

40. Shannon, R.D. Revised Effective Ionic Radii and Systematic Studies of Interatomie Distances in Halides and Chaleogenides. Acta Cryst. 1976, 32, 751-767. [CrossRef]

41. Muñoz-García, A.B.; Bugaris, D.E.; Pavone, M.; Hodges, J.P.; Huq, A.; Chen, F.; Loye, H.-C.; Carter, E.A. Unveiling structure-property relationships in $\mathrm{Sr}_{2} \mathrm{Fe}_{1.5} \mathrm{Mo}_{0.5} \mathrm{O}_{6-\delta}$, an electrode material for symmetric solid oxide fuel cells. J. Am. Chem. Soc. 2012, 134, 6826-6833. [CrossRef]

42. Porotnikova, N.M.; Khodimchuk, A.V.; Ananyev, M.V.; Eremin, V.A.; Tropin, E.S.; Farlenkov, A.S.; Pikalova, E.Y.; Fetisov, A.V. Oxygen isotope exchange in praseodymium nickelate. J. Solid State Electrochem. 2018, 22, 2115-2126. [CrossRef]

43. Porotnikova, N.M.; Antonova, E.P.; Khodimchuk, A.V.; Tropin, E.S.; Farlenkov, A.S.; Ananyev, M.V. Oxygen diffusion and surface exchange kinetics for the mixed-conducting oxide $\mathrm{La}_{0.6} \mathrm{Sr}_{0.4} \mathrm{Co}_{0.8} \mathrm{Fe}_{0.2} \mathrm{O}_{3-\delta}$. Chim. Techno Acta 2018, 5, 196-204. [CrossRef]

44. Bershitskaya, N.M.; Ananyev, M.V.; Kurumchin, E.K.; Gavrilyuk, A.L.; Pankratov, A.A. Effect of oxygen nonstoichiometry on kinetics of oxygen exchange and diffusion in lanthanum-strontium manganites. Russ. J. Electrochem. 2013, 49, 963-974. [CrossRef]

45. Ananyev, M.V.; Eremin, V.A.; Tsvetkov, D.S.; Porotnikova, N.M.; Farlenkov, A.S.; Zuev, A.Y.; Fetisov, A.V.; Kurumchin, E.K. Oxygen isotope exchange and diffusion in $\mathrm{LnBaCo}_{2} \mathrm{O}_{6-\delta}(\mathrm{Ln}=\mathrm{Pr}, \mathrm{Sm}$, Gd) with double perovskite structure. Solid State Ion. 2017, 304, 96-106. [CrossRef]

46. Ananyev, M.V.; Porotnikova, N.M.; Kurumchin, E.K. Influence of strontium content on the oxygen surface exchange kinetics and oxygen diffusion in $\mathrm{La}_{1-\mathrm{x}} \mathrm{Sr}_{\mathrm{x}} \mathrm{CoO}_{3-\delta}$ oxides. Solid State Ion. 2019, 341, 115052. [CrossRef]

47. Porotnikova, N.; Khodimchuk, A.; Tropin, E.; Antonova, E.; Ananyev, M. Oxygen isotope exchange with $\mathrm{La}_{0.6} \mathrm{Sr}_{0.4} \mathrm{Co}_{1-\mathrm{y}} \mathrm{Fe}_{\mathrm{y}} \mathrm{O}_{3-\delta}(\mathrm{y}=0.0,0.2)$ oxides. Integr. Ferroelectr. 2019, 196, 16-23. [CrossRef]

(C) 2020 by the authors. Licensee MDPI, Basel, Switzerland. This article is an open access article distributed under the terms and conditions of the Creative Commons Attribution (CC BY) license (http://creativecommons.org/licenses/by/4.0/). 